\title{
Hematological and biochemical reference values of Asian house shrews (Suncus murinus) in Bangladesh
}

Md. Kaisar Rahman ${ }^{1,2}$, Shariful Islam¹,2, Mizanur Rahman ${ }^{3}$, Jinnat Ferdous ${ }^{1,2}$, Sazeda Akter ${ }^{4}$, Md. Mustafizur Rahaman ${ }^{5}$, Mohammad Alamgir Hossain ${ }^{3}$, Mohammad Mahmudul Hassan ${ }^{6}$ and Ariful Islam ${ }^{1}$

1. EcoHealth Alliance, New York, USA; 2. Institute of Epidemiology, Disease Control and Research (IEDCR), Dhaka, Bangladesh; 3. Department of Pathology and Parasitology, Chattogram Veterinary and Animal Sciences University, Chattogram, Bangladesh; 4. Department of Medicine and Surgery, Chattogram Veterinary and Animal Sciences University, Chattogram, Bangladesh; 5. Bangladesh Forest Department, Ministry of Environment and Forests, Government of the People's Republic of Bangladesh; 6. Department of Physiology, Biochemistry and Pharmacology, Chattogram Veterinary and Animal Sciences University, Chattogram, Bangladesh.

Corresponding author: Ariful Islam, e-mail: arif@ecohealthalliance.org

Co-authors: MKR: kaisarrahman@ecohealthalliance.org, SI: sharifdvm51@gmail.com,

MR: mizanurvet@gmail.com, JF: ferdous_jinnat@yahoo.com,SA: najatdvm@gmail.com, MMR: mmustafiz@yahoo.com, MAH: hossainalamgir54@yahoo.com, MMH: miladhasan@yahoo.com

Received: 07-03-2019, Accepted: 26-08-2019, Published online: 30-09-2019

doi: 10.14202/vetworld.2019.1514-1518 How to cite this article: Rahman MK, Islam S, Rahman M, Ferdous J, Akter S, Rahaman MM, Hossain MA, Hassan MM, Islam A (2019) Hematological and biochemical reference values of Asian house shrews (Suncus murinus) in Bangladesh, Veterinary World, 12(9): 1514-1518.

\begin{abstract}
Background and Aim: Determining reference values for hematological and biochemical parameters of Asian house shrew (Suncus murinus) is important for wildlife research to protect human health in surrounding communities. This study aimed to establish the reference values for selected hematology and serum clinical chemistry analyses that may contribute to research on shrew in future.
\end{abstract}

Materials and Methods: Blood samples $(n=51)$ were collected from shrews between July and December 2015, Bangladesh, to estimate the levels of hemoglobin (Hb), packed cell volume (PCV), total leukocyte count (TLC), total erythrocyte count (TEC), lymphocyte, monocyte, neutrophil, eosinophil, basophil, calcium, phosphorus (P), sodium (Na), chloride (Cl), urea, glucose, total protein (TP), creatinine, and alanine transaminase (ALT).

Results: Although the values did not differ significantly among sexes, age was found to be a significant factor. Hb, PCV, TEC, glucose, and $\mathrm{P}$ were higher in males; eosinophil, $\mathrm{Na}, \mathrm{Cl}$, TP, and ALT were higher among females. Adults had significantly greater urea and glucose $(\mathrm{p}<0.05)$ while juveniles had insignificantly higher values for TLC, PCV, neutrophil, P, and TP.

Conclusion: This study provides the first reference values for this species in Bangladesh and can be used to guide wildlife research studies.

Keywords: Asian house shrew, hematology, reference interval, serum chemistry, Suncus murinus.

\section{Introduction}

Hematology and serum chemistry analyses are important indicators in health assessment of domestic animals and wildlife. They are also useful for identifying health disorders, drug toxicity or adverse effects, disease staging, and monitoring of response to treatment. Laboratory animals, especially shrew, rat, and mice, like their wild counterparts, are commonly used for biomedical research. There are 385 species of shrews under 26 genera all over the world. The Asian house shrew (musk shrew) (Suncus murinus, Order: Eulipotyphia, Family: Soricidae) is native to India and Southeast Asia and widely distributed throughout Bangladesh. The shrew is also natural reservoir of several zoonotic pathogens (Hantavirus, Hepatitis

Copyright: Rahman, et al. Open Access. This article is distributed under the terms of the Creative Commons Attribution 4.0 International License (http://creativecommons.org/licenses/ by/4.0/), which permits unrestricted use, distribution, and reproduction in any medium, provided you give appropriate credit to the original author(s) and the source, provide a link to the Creative Commons license, and indicate if changes were made. The Creative Commons Public Domain Dedication waiver (http:// creativecommons.org/publicdomain/zero/1.0/) applies to the data made available in this article, unless otherwise stated.
E virus, Thottapalayam virus, Borna disease virus, plague, Toxoplasma gondii, etc.) [1-3]. They are found in areas with high human activity. Therefore, they may transfer zoonotic diseases that could present threats to human health [4].

Numerous studies conducted in recent years on the blood parameters of small mammals, particularly rodents, have examined the family Soricidae. Variations in the blood parameters of shrew are extremely important in view of ecological and physiological properties of this animal. However, there are no published hematology and serum chemistry data available in Bangladesh or any other region of the Indian subcontinent for this species. Therefore, this study aimed to establish the reference values for selected hematology and serum clinical chemistry analyses that may contribute to research on shrew in the future.

\section{Materials and Methods}

\section{Ethical approval}

The Animal Experimentation Ethics Committee of Chattogram Veterinary and Animal Sciences 
University (CVASU-AEEC) approved the study protocol and the approval number for the project was CVASU/Dir (R and E) AEEC/2015/07.

\section{Study sites and subjects}

A total of 51 apparently healthy shrews were captured from Jawtala, Pahartali, and Khulshi of Chattogram, from Chakaria, Cox's bazar, and from Kaptai, Rangamati (Figure-1) during July-December, 2015. The capturing sites included hilly region, household areas, and agricultural land. Among the captured shrew, $35(69 \%)$ were male and $16(31 \%)$ were female, and $44(86 \%)$ were adults and $7(14 \%)$ were juveniles. Body weight of the animals were ranged from 40 to $195 \mathrm{~g}$. Shrew capture and sample collection were performed following the procedure described elsewhere [5]. Animals were categorized into adult and juvenile based on their appearances described in PREDICT One Health Consortium [6].

\section{Blood sample collection and analysis}

Shrews were captured primarily to identify gastrointestinal parasites after postmortem. After anesthesia, blood samples (1-2 mL/animal) were collected directly from the heart opportunistically. Blood was immediately transferred into two tubes, one without anticoagulant for smooth coagulation and the other with EDTA. After coagulation in the vacutainer, the blood was centrifuged at $3000 \mathrm{rpm}$ for $15 \mathrm{~min}$. Serum samples were obtained and stored in $-20^{\circ} \mathrm{C}$. The blood samples were analyzed using Hemolyzer 3000 and hematological parameters such as hemoglobin $(\mathrm{Hb})$, erythrocyte sedimentation rate and packed cell volume (PCV), level of calcium $(\mathrm{Ca})$, phosphorus $(\mathrm{P})$, sodium $(\mathrm{Na})$, chloride (Cl), urea, glucose, total protein (TP), creatinine, and alanine aminotransferase were estimated. Red blood cells (total erythrocyte count) and white blood cells were manually estimated and counted [7].

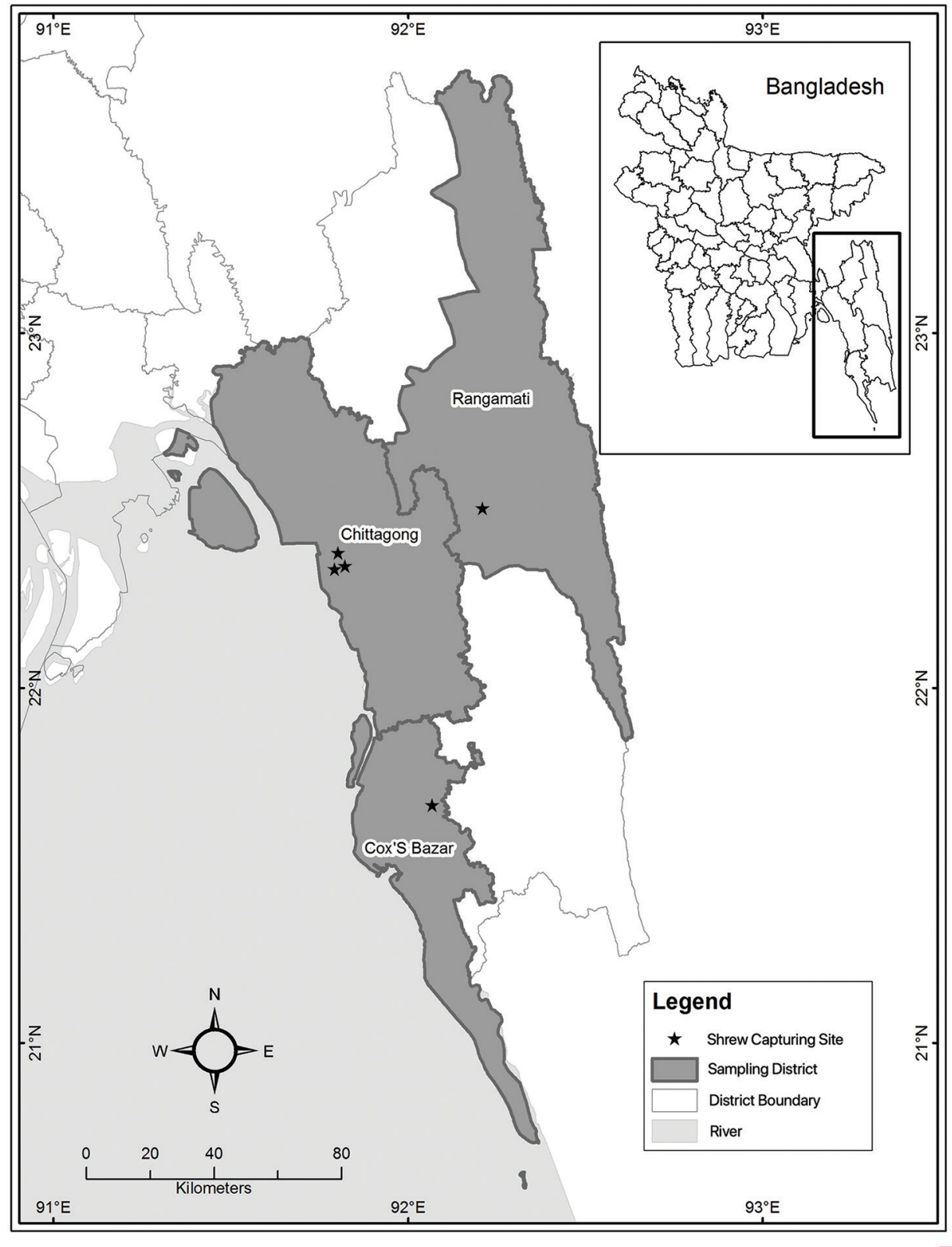

Figure-1: Distribution of Asian house shrews (Suncus murinus) capturing sites in Bangladesh Jul-Dec, 2015. 


\section{Statistical analysis}

Collected data were recorded in Microsoft Excel 2007 (Microsoft Corporation, Redmond, WA 980526399, USA) and imported into MedCalc Statistical Software version 17.5.5 (MedCalc Software bvba, Ostend, Belgium; http://www.medcalc.org; 2017) for estimating mean, standard deviation (SD), and reference intervals (RIs). Robust method was used to calculate RIs because the number of samples collected was 51 . The $90 \%$ confidence intervals (CIs) were calculated for each RI using bootstrap methods according to Rahman et al. [5], Friedrichs et al. [8]. Data were presented as mean, $\mathrm{SD}$, minimum, and maximum with
90\% CI. Differences between the hematology and serum biochemistry parameters of male and female, adult and juvenile house shrews were analyzed using Student's t-test or Mann-Whitney test depending on their distribution in histogram. $\mathrm{p}<0.05$ was considered to be statistically significant.

\section{Results}

The results of the blood parameters and serum chemistry analysis (mean, SD, minimum, maximum, and RI - lower limit and upper limit) are given in Table-1. The comparative level of blood parameters and serum chemistry between males and females,

Table-1: Hematological and biochemical parameters of Asian house shrews (Suncus murinus) ( $\mathrm{n}=51$ ) with upper and lower limit of reference interval.

\begin{tabular}{|c|c|c|c|c|c|c|}
\hline Parameter & Mean & SD & Min. & Max. & RI lower limit (90\% CI) & RI upper limit (90\% CI) \\
\hline $\mathrm{Hb}$ & 13.3 & 1.1 & 11.2 & 15.2 & $11.3(10.8-11.7)$ & $15.4(14.9-15.8)$ \\
\hline PCV & 39.9 & 3.3 & 33.4 & 45.6 & $33.39(32.1-34.7)$ & $46.4(45.1-47.7)$ \\
\hline TLC & 7.2 & 2.3 & 4.2 & 11.3 & $2.80(1.9-3.7)$ & $11.6(10.7-12.6)$ \\
\hline TEC & 4.8 & 0.9 & 2.5 & 7.13 & $2.91(2.5-3.3)$ & $6.6(6.2-6.9)$ \\
\hline Lymphocyte & 47.2 & 7.9 & 29 & 60 & $31.65(28.4-34.9)$ & $62.8(59.6-66.1)$ \\
\hline Neutrophil & 42.4 & 6.9 & 31 & 58 & $28.84(26.1-31.6)$ & $55.9(53.2-58.8)$ \\
\hline Eosinophil & 5.2 & 2.2 & 2 & 11 & $0.81(-0.09-1.7)$ & $9.6(8.7-10.5)$ \\
\hline Monocyte & 4.8 & 1.9 & 2 & 9 & $1.13(0.4-1.9)$ & $8.5(7.8-9.3)$ \\
\hline Basophil & 0.3 & 0.48 & 0 & 1 & $-0.59(-0.8--0.4)$ & $1.26(1.1-1.5)$ \\
\hline Calcium & 12.3 & 1.2 & 8.8 & 13.9 & $9.96(9.5-10.4)$ & $14.6(14.1-15.0)$ \\
\hline Phosphorus & 17.5 & 6.5 & 10.2 & 35.7 & $4.9(2.3-7.5)$ & $30.2(27.6-32.7)$ \\
\hline Sodium & 182.9 & 21.0 & 133.2 & 218.9 & $141.8(133.4-150.2)$ & $224.2(215.7-232.6)$ \\
\hline Chloride & 136.9 & 11.3 & 112.3 & 161.5 & $114.7(110.2-119.3)$ & $159.2(154.6-163.7)$ \\
\hline Urea & 50.5 & 8.1 & 36.3 & 67.6 & $34.7(31.4-37.9)$ & $66.3(63.1-69.6)$ \\
\hline Glucose & 128.4 & 17.2 & 97.3 & 164.9 & $94.6(87.7-101.5)$ & $162.1(155.2-169.1)$ \\
\hline TP & 7.8 & 2.8 & 3.9 & 13.5 & $2.2(1.0-3.4)$ & $13.5(12.3-14.6)$ \\
\hline Creatinine & 0.6 & 0.2 & 0.3 & 1.2 & $0.2(0.1-0.3)$ & $1.1(1.0-1.2)$ \\
\hline ALT & 42.9 & 7.2 & 19.7 & 56.4 & $28.8(25.9-31.6)$ & $57.1(54.1-59.9)$ \\
\hline
\end{tabular}

$\mathrm{SD}=$ Standard deviation, Min.=Minimum, Max.=Maximum, RI=Reference interval, CI=Confidence interval,

$\mathrm{Hb}=$ Hemoglobin, $\mathrm{PCV}=$ Packed cell volume, TLC=Total leukocyte count, $\mathrm{TEC}=$ Total erythrocyte count, TP=Total protein, $\mathrm{ALT}=$ Alanine aminotransferase

Table-2: Comparison of hematology and biochemistry between clinically healthy male and female, adult and juvenile Asian house shrews (Suncus murinus).

\begin{tabular}{|c|c|c|c|c|c|c|c|c|c|c|c|c|c|c|}
\hline \multirow[t]{2}{*}{ Analytes } & \multicolumn{3}{|c|}{ Male $(n=35)$} & \multicolumn{3}{|c|}{ Female $(n=16)$} & \multirow[t]{2}{*}{ p-value } & \multicolumn{3}{|c|}{ Adult $(n=44)$} & \multicolumn{3}{|c|}{ Juvenile $(n=7)$} & \multirow[t]{2}{*}{ p-value } \\
\hline & Mean & $\begin{array}{l}\text { Std. } \\
\text { dev. }\end{array}$ & $\begin{array}{l}\text { Std. } \\
\text { err. }\end{array}$ & Mean & $\begin{array}{l}\text { Std. } \\
\text { dev. }\end{array}$ & $\begin{array}{l}\text { Std. } \\
\text { err. }\end{array}$ & & Mean & $\begin{array}{l}\text { Std. } \\
\text { dev. }\end{array}$ & $\begin{array}{l}\text { Std. } \\
\text { err. }\end{array}$ & Mean & $\begin{array}{l}\text { Std. } \\
\text { dev. }\end{array}$ & $\begin{array}{l}\text { Std. } \\
\text { err. }\end{array}$ & \\
\hline $\mathrm{Hb}$ & 13.4 & 0.98 & 0.16 & 13.16 & 1.19 & 0.29 & 0.41 & 13.25 & 1.06 & 0.16 & 13.8 & 0.9 & 0.3 & 0.13 \\
\hline PCV & 40.1 & 3.24 & 0.55 & 39.45 & 3.54 & 0.89 & 0.49 & 39.58 & 3.30 & 0.49 & 41.8 & 2.8 & 1.1 & 0.07 \\
\hline TLC & 7.1 & 2.34 & 0.39 & 7.57 & 2.08 & 0.52 & 0.44 & 6.98 & 2.15 & 0.32 & 8.8 & 2.4 & 0.9 & 0.09 \\
\hline TEC & 4.9 & 0.89 & 0.15 & 4.54 & 1.05 & 0.26 & 0.26 & 4.73 & 0.91 & 0.14 & 4.9 & 1.2 & 0.4 & 0.56 \\
\hline Lymphocyte & 47.4 & 8.25 & 1.39 & 47 & 7.55 & 1.87 & 0.79 & 47.91 & 7.69 & 1.16 & 43.1 & 9.0 & 3.4 & 0.15 \\
\hline Neutrophil & 42.5 & 6.92 & 1.17 & 42.31 & 7.16 & 1.79 & 0.97 & 41.95 & 6.86 & 1.03 & 45.3 & 7.1 & 2.7 & 0.18 \\
\hline Eosinophil & 4.9 & 2.16 & 0.37 & 5.75 & 2.41 & 0.60 & 0.31 & 5.05 & 2.26 & 0.34 & 6.3 & 1.9 & 0.7 & 0.09 \\
\hline Monocyte & 4.89 & 1.88 & 0.32 & 4.69 & 1.9 & 0.5 & 0.74 & 4.82 & 1.9 & 0.3 & 4.9 & 1.8 & 0.7 & 0.93 \\
\hline Basophil & 0.34 & 0.5 & 0.1 & 0.3 & 0.5 & 0.1 & 0.83 & 0.3 & 0.5 & 0.07 & 0.4 & 0.5 & 0.2 & 0.57 \\
\hline Calcium & 12.3 & 1.2 & 0.2 & 12.2 & 1.1 & 0.3 & 0.64 & 12.3 & 1.1 & 0.2 & 12.2 & 1.7 & 0.6 & 0.65 \\
\hline Phosphorus & 17.9 & 7.0 & 1.2 & 16.6 & 5.1 & 1.3 & 0.85 & 16.9 & 6.0 & 0.9 & 21.3 & 8.2 & 3.1 & 0.12 \\
\hline Sodium & 181.4 & 21.9 & 3.7 & 186.5 & 19.2 & 4.8 & 0.4 & 182.2 & 22.1 & 3.3 & 187.9 & 11.3 & 4.3 & 0.51 \\
\hline Chloride & 135.9 & 10.9 & 1.86 & 139.2 & 12.2 & 3.1 & 0.4 & 136.5 & 11.5 & 1.7 & 139.6 & 10.6 & 4.0 & 0.52 \\
\hline Urea & 50.7 & 8.7 & 1.5 & 50 & 6.8 & 1.7 & 0.69 & 51.4 & 8.01 & 1.2 & 44.7 & 6.3 & 2.4 & $0.03 *$ \\
\hline Glucose & 129.8 & 17.8 & 3.0 & 125.2 & 15.9 & 3.9 & 0.39 & 130.4 & 16.4 & 2.5 & 115.4 & 18.1 & 6.2 & $0.04^{*}$ \\
\hline TP & 7.5 & 2.8 & 0.5 & 8.5 & 3.1 & 0.8 & 0.28 & 7.6 & 2.8 & 0.4 & 9.1 & 3.1 & 1.2 & 0.18 \\
\hline Creatinine & 0.6 & 0.2 & 0.04 & 0.7 & 0.3 & 0.1 & 0.14 & 0.7 & 0.2 & 0.04 & 0.7 & 0.23 & 0.09 & 0.45 \\
\hline ALT & 42.1 & 7.9 & 1.4 & 44.7 & 4.9 & 1.2 & 0.2 & 42.8 & 7.6 & 1.2 & 42.84 & 4.18 & 1.5 & 0.99 \\
\hline
\end{tabular}

Std. dev.=Standard deviation, Std. err. =Standard error, Hb=Hemoglobin, PCV=Packed cell volume, TLC=Total leukocyte count, TEC=Total erythrocyte count, $\mathrm{TP}=$ Total protein, ALT=Alanine aminotransferase, $*=$ Significant 
adult and juveniles is shown in Table-2. Levels did not vary significantly between males and females. Juveniles showed higher levels of PCV, total leukocyte count (TLC), neutrophils, eosinophils, $\mathrm{P}, \mathrm{Na}$, $\mathrm{Cl}$, and TP, whereas adult shrews had higher levels of lymphocyte, urea, and glucose. Among the samples, the mean urea $(51.43 \mathrm{mmol} / \mathrm{L})$ and glucose $(130.43 \mathrm{mg} / \mathrm{dL})$ levels were significantly higher $(p<0.04)$ in adults compared to juveniles. Elevated mean values were observed for lymphocytes $(47.91 \%)$ in adults but for PCV $(41.83 \%)$, neutrophils $(45.29 \%), \mathrm{P}(21.35 \mathrm{mg} / \mathrm{dL})$, and TP $(9.13 \mathrm{~g} / \mathrm{dL})$ in juveniles (Table-2).

\section{Discussion}

Samples were collected from shrews in their natural environment, which is important for captive laboratory animals. In this study, all animals were clinically healthy so the values found were in normal ranges as expected. TLC count was within reference value, but juveniles showed higher TLC values. It was found that hematological values vary along with age and sex in case of Crocidura russula [9]. While not found to be statistically significant in this study, $\mathrm{Hb}$ and PCV were higher in males than in female shrews, matching similar findings previously reported by Crofton and Share [10]. This is maybe the potential influence of the estrus cycle in female. During proestrus, estrus, and metestrus, the PCV level decreases in female. The percentage of PCV also varies due to age, sea level, altitude, and in some disease situations (e.g., during periods of difficult breathing or dehydration) [11]. Blood glucose concentration was found to be higher in male tree shrews (Tupaia belangeri chinensis) in a previous study [12]. Female tree shrews have significantly lower body weight and fasting blood glucose concentration than males $(p<0.001)$ [12]. The concentration of fasting blood glucose was slightly increased with body weight in males; but the body weight, concentration of fasting blood glucose positively increased with age $(\mathrm{p}<0.001)$, which is similar to the current study findings. The study revealed that mean urea level is significantly higher in adults (51.43 $\mathrm{mmol} / \mathrm{L}$ ) than in juveniles; this is expected as urea is a primary metabolic product of protein metabolism, which increases with age [13]. Protein quality tests, therefore, should be performed among the same age groups for significant results. No significant variation was found in the level of $\mathrm{Na}$ and $\mathrm{Cl}$ between adults and juveniles, but both were higher in juveniles than in adults, which support a previous study [14]. TP and creatinine were within the reference range which is relatively similar to the result found in the study of Mock et al. [15]. The house shrew showed similar glucose and P level to the least shrew, but the other parameter values were higher in the house shrew [15]. Compared to the previous findings reported for Webster mice, $\mathrm{Hb}, \mathrm{TP}, \mathrm{Ca}$, and P levels were higher in house shrews in this study [16].

\section{Conclusion}

Although the sample size was small, this study establishes hematological and biochemical reference values for the house shrew to assist in the detection of possible pathologies caused by zoonotically significant organisms. This is the first systematic report of hematology and plasma biochemistry parameters in apparently healthy free-range Asian house shrew and may serve as a reference for clinical assessment and future study of this species.

\section{Authors' Contributions}

$\mathrm{AI}$ initiated and planned the research. SI and MR collected the samples. MR and SA carried out the laboratory work. MKR and JF did a literature review, data analysis, and prepared the draft. SI, MMR, MAH, $\mathrm{MMH}$, and AI made the necessary corrections over the entire manuscript. All authors read and approved the final manuscript.

\section{Acknowledgments}

We thank Abdullah Al Mamun, Pitu Biswas, Md. Gafur Sheikh and Abdul Hai for assistance in the fieldwork and technical support. We are also grateful to the staffs of the Department of Physiology, Pharmacology and Bio-Chemistry, CVASU, for their help during laboratory examination. This study was made possible by the generous support of the American people through the United States Agency for International Development (USAID) Emerging Pandemic Threats PREDICT (cooperative agreement number GHNA-OO-09-00010-00). The contents are the responsibility of the authors and do not necessarily reflect the views of USAID or the United States Government.

\section{Competing Interests}

The authors declare that they have no competing interests.

\section{Publisher's Note}

Veterinary World remains neutral with regard to jurisdictional claims in published map and institutional affiliation.

\section{References}

1. Guterres, A. and de Lemos, E.R.S. (2018) Hantavirus and a neglected environmental determinant. One Health, 5: 27-33.

2. Rahelinirina, S., Rajerison, M., Telfer, S., Savin, C., Carniel, E. and Duplantier, J.M. (2017) The Asian house shrew Suncus murinus as a reservoir and source of human outbreaks of plague in Madagascar. PLoS Negl. Trop. Dis., 11(11): e0006072.

3. Nobach, D., Bourg, M., Herzog, S., Lange-Herbst, H., Encarnacao, J.A., Eickmann, M. and Herden, C. (2015) Shedding of infectious Borna disease virus-1 in living bicolored white-toothed shrews. PLoS One, 10(8): e0137018.

4. Wang, W., Lin, X.D., Liao, Y., Guan, X.Q., Guo, W.P., Xing, J.G., Holmes, E.C. and Zhang, Y.Z. (2017) Discovery of a highly divergent coronavirus in the Asian house shrew from China illuminates the origin of the alphacoronaviruses. J. Virol., 91(17): 764-717.

5. Rahman, M., Islam, S., Masuduzzaman, M., Alam, M., 
Chawdhury, M.N.U., Ferdous, J., Islam, M.N., Hassan, M.M., Hossain, M.A. and Islam, A. (2018) Prevalence and diversity of gastrointestinal helminths in free-ranging Asian house shrew (Suncus murinus) in Bangladesh. Vet. World., 11(4): 549.

6. PREDICT One Health Consortium. USAID PREDICT Project PREDICT Operating Procedures: Rodent Sampling Methods.

7. Rahman, M.K., Islam, S., Ferdous, J., Uddin, M.H., Hossain, M.B., Hassan, M.M. and Islam, A. (2018) Determination of hematological and serum biochemical reference values for indigenous sheep (Ovies aries) in Dhaka and Chittagong districts of Bangladesh. Vet. World, 11(8): 1089.

8. Friedrichs, K.R., Harr, K.E., Freeman, K.P., Szladovits, B., Walton, R.M., Barnhart, K.F. and Blanco-Chavez, J. (2012) ASVCP reference interval guidelines: Determination of de novo reference intervals in veterinary species and other related topics. Vet. Clin. Pathol., 41(4): 441-453.

9. Sánchez-Chardi, A., Marques, C., Gabriel, S., Capela-Silva, F., Cabrita, A., López-Fuster, M., Nadal, J. and Mathias, M.D.L. (2008) Haematology, genotoxicity, enzymatic activity and histopathology as biomarkers of metal pollution in the shrew Crocidura russula. Environ. Pollut., 156(3): 1332-1339.

10. Crofton, J.T. and Share, L. (1990) Sexual dimorphism in vasopressin and cardiovascular response to hemorrhage in the rat. Circ. Res., 66(5): 1345-1353.

11. Sawin, C.F. (1970) Hematology of sea-level wand high-altitude native Sonoran deer mice. Am. J. Physiol., 218(6): 1701-1703.

12. Wu, X., Chang, Q., Zhang, Y., Zou, X., Chen, L., Zhang, L., Lv, L. and Liang, B. (2013) Relationships between body weight, fasting blood glucose concentration, sex and age in tree shrews (Tupaia belangeri chinensis). J. Anim. Physiol. Anim. Nutr., 97(6): 1179-1188.

13. Eggum, B., Thorbek, G., Beames, R., Chwalibog, A. and Henckel, S. (1982) Influence of diet and microbial activity in the digestive tract on digestibility, and nitrogen and energy metabolism in rats and pigs. Br. J. Nutr., 48(1): 161-175.

14. Kirk, J., Keston, M., McIntosh, I. and Essa, S.A. (1992) Variation of sweat sodium and chloride with age in cystic fibrosis and normal populations: Further investigations in equivocal cases. Ann. Clin. Biochem., 29(2): 145-152.

15. Mock, O.B., Casteel, S.W., Darmani, N.A., Shaddy, J.H., Besch-Williford, C. and Towns, L.C. (2001) Anatomic and physiologic reference values in least shrews (Cryptotis parva). Comp. Med., 51(6): 534-537.

16. Santos, E.W., Oliveira, D.C.D., Hastreiter, A., Silva, G.B.D., Beltran, J.S.D.O., Tsujita, M., Crisma, A.R., Neves, S.M.P., Fock, R.A. and Borelli, P. (2016) Hematological and biochemical reference values for C57BL/6, swiss webster and BALB/c mice. Braz. J. Vet. Res. Anim. Sci., 53(2): 138-145.

$* * * * * * * *$ 